\title{
КОРРЕЛЯЦИОННЫЙ АНАЛИЗ ОСНОВНЫХ ГРАНИЦ ОСАДОЧНОГО ЧЕХЛА СЕВЕРО-УСТЮРТСКОГО РЕГИОНА
}

\author{
Абетов Ауэз Егембердыевич', \\ abetov.auez@mail.ru \\ Волож Юрий Абрамович², \\ yvolozh@yandex.ru \\ Ниязова Акмарал Темирхановна', \\ niyazova.akma@mail.ru \\ Казахский национальный исследовательский технический университет им. К.И. Сатпаева, \\ Казахстан, 050013, Алматы, ул. Сатпаева, 22. \\ 2 Институт геологических наук РАН, \\ Россия, г. Москва, 119017, Пыжевский пер., стр. 7.
}

\begin{abstract}
Актуальность исследования обусловлена необходимостью наращивания ресурсной базы Республики Казахстан за счет открытия новых месторождении нефти и газа в Северо-Устюртском регионе. Цель: определение корреляционной связи структурных элементов крупных геоструктур Северо-Устюртского региона. Объекты: поверхности фундамента и палеозоя, подошвы юрских и меловых отложений Северо-Устюртского региона. Методы: переведение в цифровой формат серии структурных карт: по поверхности фундамента, палеозоя, доюрской поверхности, подошве мела Северо-Устюртской региона с помощью программных средств Didger, Surfer, ArcGlS, Geosoft; количественный корреляционный анализ основных геологических границ в программном комплексе COSCAD 3D.

Результаты. В Устюртском регионе по характеру коррелируемости поверхности фундамента и палеозоя, подошвы юрских и меловых отложений выделены три группы геоструктур. В первую группу вошли подвижные складчатые системы и «мобильные углы”, в которых коэффициенты корреляции вышеуказанных границ проявляются слабо либо не проявляются вовсе (Южно-Эмбенское поднятие, Арало-Кызылкумский вал, Центрально-Устюртская система дислокации, Горный Мангышлак). Вторую группу формируют внутренние мобильные элементы, обособляющиеся как крупные положительные структуры характеризующиеся экстремально высокими значениями коэффициентов корреляции по поверхности фундамента и палеозоя, подошвы юрских и меловых отложений, (Бузачинский выступ, Актумсукское поднятие, Куаныш-Коскалинский вал, Байчагыр-Яркимбайский свод). Третью группу геоструктур образуют тектонические элементы внутренних районов Северо-Устюртского региона (Северо-Устюртская система прогибов, Челкарская и Барсакельмесская депрессии), характеризующиеся длительным и унаследованным прогибанием в фанерозое и высокой коррелируемостью поверхности фундамента и палеозоя, подошвы юры и мела.
\end{abstract}

\section{Ключевые слова:}

Северный Устюрт, поверхность фундамента, поверхность палеозоя, подошва юры, подошва мела, коэффициент корреляции.

\section{Постановка задачи и ретроспективный анализ}

Исследования геологического строения СевероУстюртской впадины сейсмическими методами и бурением начались с середины XX в. и проводились различными организациями Казахстана, Узбекистана, Туркмении, России. Начиная с 2000-х гг. - рядом нефтяных компаний из дальнего зарубежья [1].

Первые сведения о геологии Северного Устюрта были получены в начале 1950-х гг. после проведения сейсмических работ методами отраженных и переломленных волн (МОВ и КМПВ). По результатам интерпретации полученных данных были уточнены старые и выявлены новые структурные элементы, составлены карты тектонического районирования чехла и фундамента [2].

К концу 1960-х гг. Турланской геофизической экспедицией были выполнены региональные работы КМПВ, направленные на изучение нижних горизонтов осадочного чехла и поверхности консолидированной коры. Эти работы позволили определить региональную структуру и характер изменения мощностей палеозойско-триасовых отложе- ний, сделать обоснованные фактическим материалом первые выводы о строении фундамента Устюртского региона $[2,3]$.

70-е и 80-е гг. прошлого столетия характеризуются значительным ростом объёмов геолого-геофизических работ, интенсивным накоплением данных о структуре, вещественном составе и стратиграфии мезо-кайнозойских и палеозойско-триасовых отложений. В этот период были отработаны региональные и поисковые профили методом общей глубинной точки (МОГТ) [1].

В результате этих работ была выявлена зона нефтегазонакопления на п-ове Бузачи, где в юрских и меловых отложениях последующими работами были выявлены залежи нефти на месторождениях Каламкас, Каражанбас и Северный Бузачи.

К середине 1990-х гг. практически на всей территории Северного Устюрта (в Казахской части) завершена отработка региональной сети сейсмических профилей КМПВ и МОГТ; выполнен большой объем поисковых и детальных сейсмических работ МОГТ по выявлению и подготовке локальных 
структур в юрско-палеогеновой секции разреза осадочного чехла [4].

Выявлены структуры Акшокы, Зап. Акшокы, Кыземшек, Зап. Кушата, Ю. Акжигит, Азамат, Елигажи, Жалгиз, Зап. Каратюлей, Киндыкты по ОГ «б» (поверхность палеозойских отложений доартинского возраста), а также структуры Мухтар и Коныр по ОГ V1 [4].

В восточной части Северного Устюрта, у границы с Узбекистаном, выполнены поисковые сейсморазведочные работы МОГТ фирмой MSUP (с финансированием из США).

По Самскому прогибу, в том числе и по его северном борту, получены новые дополнительные сведения о геологическом строении. Доюрские отложения этого прогиба отнесены в разряд малоперспективных. При этом сделан вывод о том, что палеозойские отложения могли быть источником углеводородов для юрских отложений.

Более информативный материал, по разрешающей способности, при сейсморазведочных работах получен в 1995-2002 гг. на площадях, где эти исследования выполнялись за счет иностранных инвестиций с наиболее современной аппаратурой. Эти площади отработаны MOГT-2D Японской национальной нефтяной компании (ЯННК) и расположены на северо-западном побережье Аральского моря (1995-1997 гг.), на акватории Аральского моря (2000-2001 гг.), на площади «Терескен» в зоне сочленения Прикаспийской впадины и Устюрта (1997-1998 гг.) и на соре Кайдак (1999-2000 гг.) [5].

К настоящему времени вся территория СевероУстюртского региона покрыта региональной сетью сейсмических профилей КМПВ и МОГТ и площадными поисково-детальными исследованиями MOB, а затем, с 1980-х гг., - МОГТ [1].

По результатам выполненных сейсмических исследований и с привлечением данных по геофизическим потенциальным полям установлены основные черты тектоники Устюрта, составлены карты тектонического районирования чехла и фундамента и выделены зоны, перспективные на нефть и газ, охарактеризованы породы фундамента.

Большой вклад в познание геологии и нефтегазоносности Северного Устюрта внесли статьи и монографии А.А. Бакирова, Р.Б. Сапожникова, Н.Я. Кунина, Ю.А. Воложа, 3.Е. Булекбаева, А.М. Акрамходжаева, Р.Г. Гарецкого, Р. И. Быкова, В.П. Гаврилова, И.Б. Дальяна, Н.А. Калинина, Л.К. Кирюхина, В.С. Князева, С.М. Оздоева, А.Е. Абетова, В.В. Липатовой, Ю.М. Васильева, И.Г. Гринберга, Г.Х. Дикенштейна, Б.Ф. Дьякова, Н.В. Неволина, Я.М. Огородникова, В.И. Шрайбмана, А.Л. Яншина, Э.С. Воцалевского и др.

Вместе с тем количественный корреляционный анализ основных геологических границ осадочного чехла и консолидированной коры до сих пор не выполнен. В целях изучения структурных особенностей и взаимоотношений структурных поверхностей в программном комплексе COSCAD 3D pacсчитан коэффициент корреляции (полный спек- трально-корреляционный анализ геоданных) серии структурных карт: по поверхности фундамента, палеозоя, доюрской поверхности, подошве мела Северо-Устюртской региона [6, 7].

Важно отметить, что программное обеспечение COSCAD 3D дает возможность провести полный спектрально-корреляционный и статистический анализ геоданных. Разработано оно в Московском Государственном геологоразведочном Университете под руководством докторов физико-математических наук, профессоров А.А. Никитина и А.В. Петрова.

Картографические материалы, использованные в наших исследованиях, были заимствованы из базы данных Института геологических наук им. К.И. Сатпаева (А.А. Абдулин, Э.С. Воцалевский, С.Ж. Даукеев, 1997) и переведены в цифровой формат с помощью программных средств Didger, Surfer, ArcGIS, Geosoft.

В геологическом строении Северо-Устюртского региона выделяются стабильные глыбы, к которым относятся его внутренние районы и крупные линейно-вытянутые мобильные пояса (Центрально-Устюртская система дислокаций, Горный Мангышлак, Южно-Эмбенское поднятие и Арало Кызылкумский вал), расположенные в периферийных зонах и внутренних «мобильных углах» этого региона [8].

\section{Результаты корреляционные анализа основных} границ раздела Северо-Устюртского региона

Центрально-Устюртская систела дислокаuий. Отчетливо выраженная линейная структура, вытянутая в запад-северо-западном направлении и осложненная валообразными поднятиями и прогибами более высоких порядков [9].

В центральной части этой системы дислокаций поверхность консолидированного фундамента залегает на глубинах 4,0-6,0 км. Поверхность палеозоя, подошва юры и мела залегают здесь конформно фундаменту и с некоторыми вариациями идентифицируются в интервалах глубин 2,5-3,5 км (поверхность палеозоя), 1,8-2,0 км (подошва юрских образований) и 1,2-1,6 км (подошва меловых образований).

Коэффициент корреляции между фундаментом и поверхностью палеозоя повсеместно приобретает высокие значения (до 0,8-0,9).

По поверхности фундамента и подошве юрских образований в западной части ЦентральноУстюртской системы дислокаций наблюдается антиформное залегание с коэффициентом корреляции $-0,4--0,6$, на остальной части этой крупной геоструктуры фиксируются высокие значения коррелируемости поверхности фундамента и подошвы юры - до 0,8.

По поверхности фундамента и подошве меловых образований наблюдается схожая картина. В западной части Центрально-Устюртской системы дислокаций выявлены отрицательные значения коэффициента корреляции (до -0,4). На остальной 


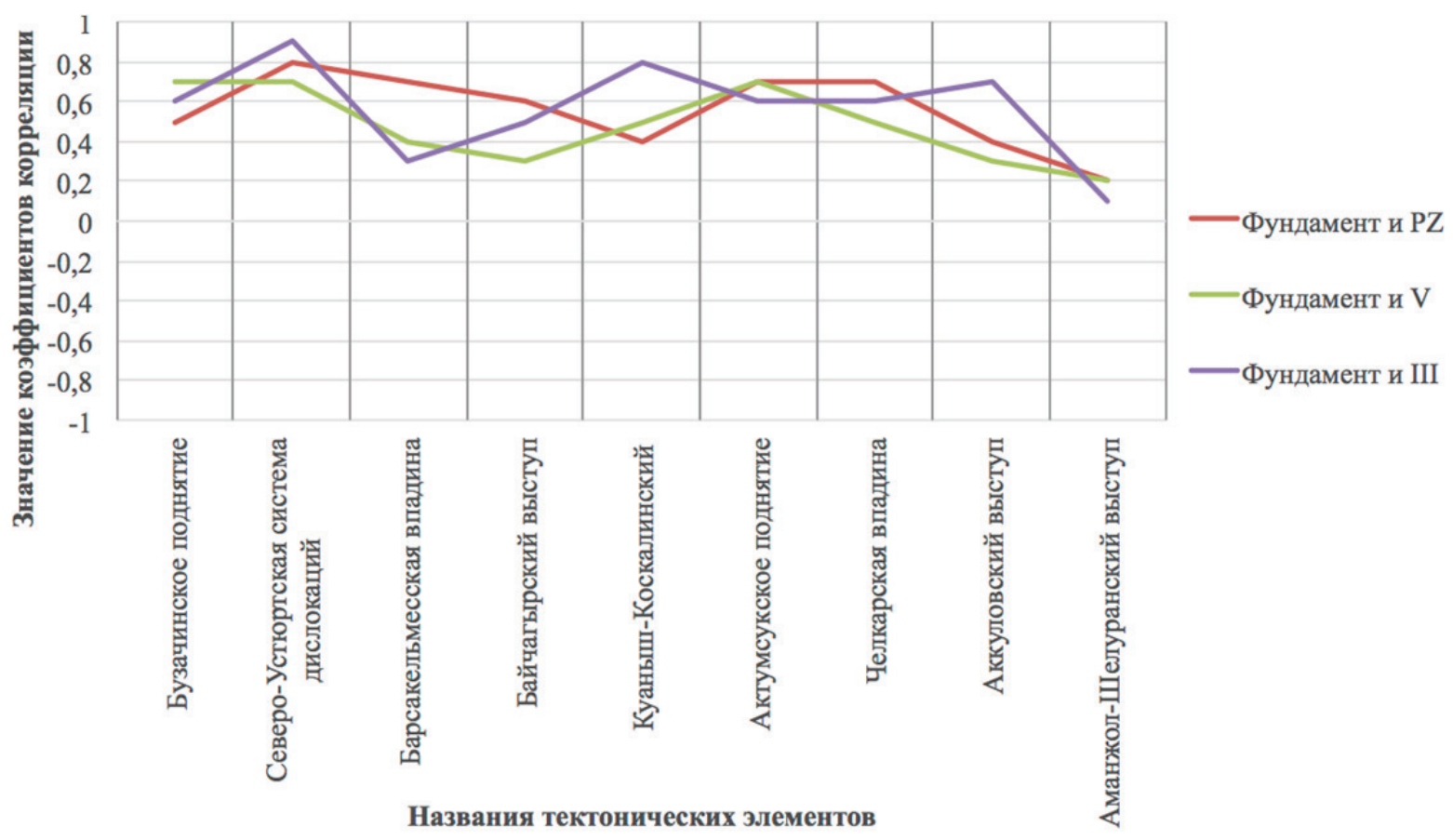

Pис. 1. График средних значении коэффиииентов корреляиии внутренних районов Северо-Устюртского региона

Fig. 1. Graph of average values of the correlation coefficients of the internal areas of the North-Ustyurt region

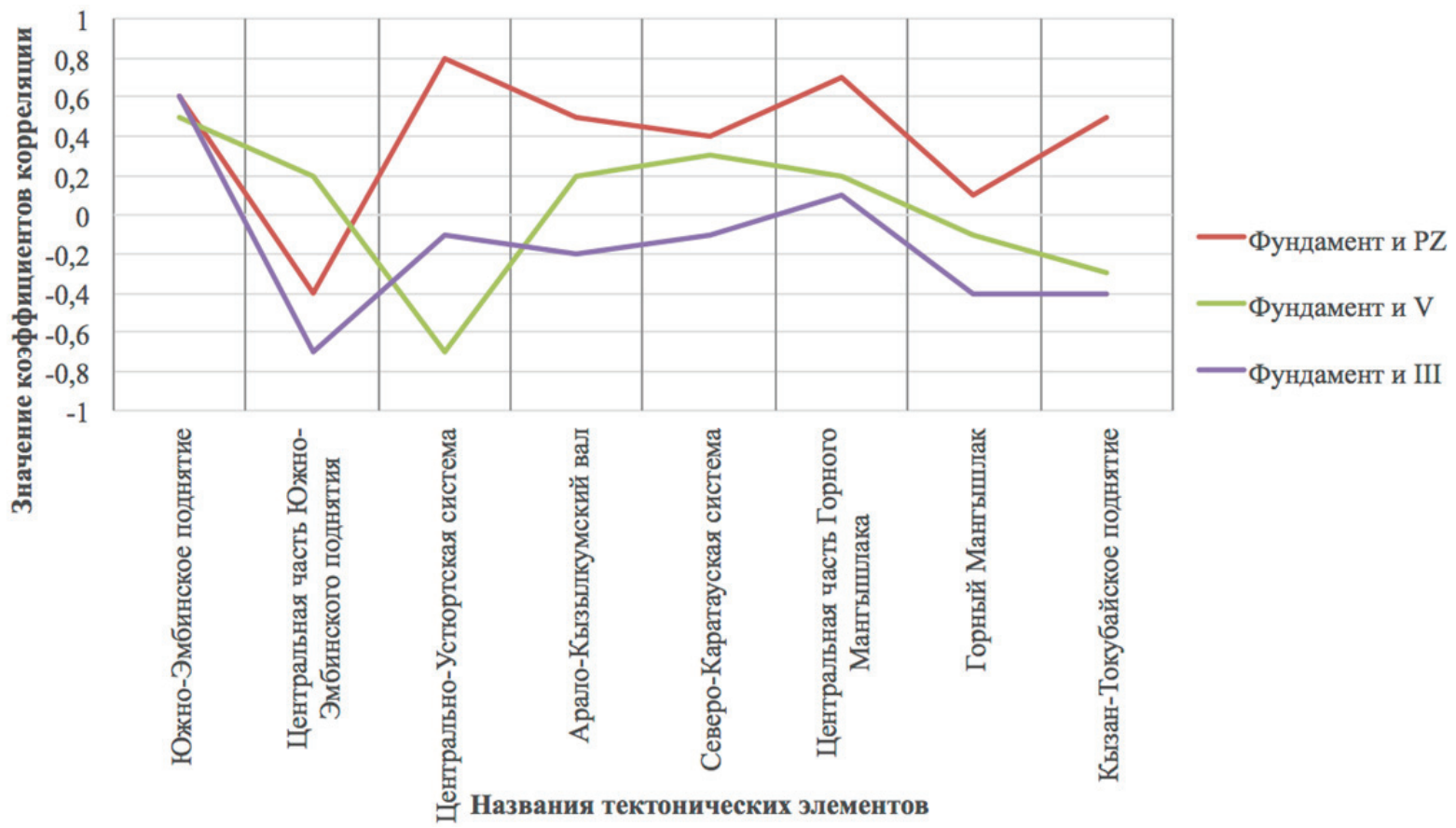

Pис. 2. График средних значении коэффициентов корреляиии «мобильных углов» Северо-Устюртского региона

Fig. 2. Graph of average values of the correlation coefficients of the «mobile corners» of the North-Ustyurt region

части этой геоструктуры значения коэффициента корреляции увеличиваются до 0,7.

Бузачинский свод. Выделяется в западном углу Северного Устюрта и имеет продолжение в акваторию Каспийского моря.

На северо-западе Бузачинского свода кровля фундамента прослеживается на глубинах порядка
6,0-7,0 км, погружаясь до 8,0 км в южном и восточном направлениях.

В гипсометрически приподнятых участках этого свода фундамент слабо коррелируется с поверхностью палеозойских образований $(0,2)$, тогда как в южном направлении этот коэффициент увеличивается до 0,6 (рис. 1). 
Палеозойские комплексы пород здесь широко развиты. В своде Бузачинского поднятия поверхность палеозойских образований залегает на глубинах до 2,5 км и более, погружаясь до $6,5-7,0$ км на южной и восточной периклиналях этого поднятия.

Подошва юрских отложений выделяется на глубинах до 0,6 км в северо-западной части Бузачинского свода, погружаясь к югу и востоку до 1,6 км. Диапазон глубин залегания подошвы меловых образований изменяется в пределах $0,6-1,2$ км.

Наблюдается хорошая коррелируемость подошвы юрских и меловых отложений с поверхностью фундамента $(0,6-0,7)$ (рис. 2,3$)$.

Горный Мангышлак. Глубина залегания фундамента здесь повсеместно выдержана и принимает значения 6,0-7,0 км (включая Северо-Кара- таусский и Чакырганский прогибы). Поднятия Горного Мангышлака обособляются в форме узких (порядка 20 км) и протяженных (до нескольких сот км) поднятий - мегантиклиналей [10].

Поверхность палеозоя Горного Мангышлака обособляется на глубинах $3,0-4,5$ км и выше.

Коэффициенты корреляции фундамента и поверхности палеозоя принимают минимальные значения (от 0,1 до $-0,6)$ на северо-западном и юговосточном флангах. В центральной части Горного Мангышлака фундамент и поверхность палеозоя залегает конформно с высоким коэффициентом корреляции (до 0,8) (рис. 1, 2).

В рельефе подошвы юрских отложений Горный Мангышлак обособляется в виде поднятии по абсолютным отметкам $-1,6--2,0$ км. Коэффициенты корреляции фундамента и подошвы юрских отложений распределяется аналогичным образом. От-

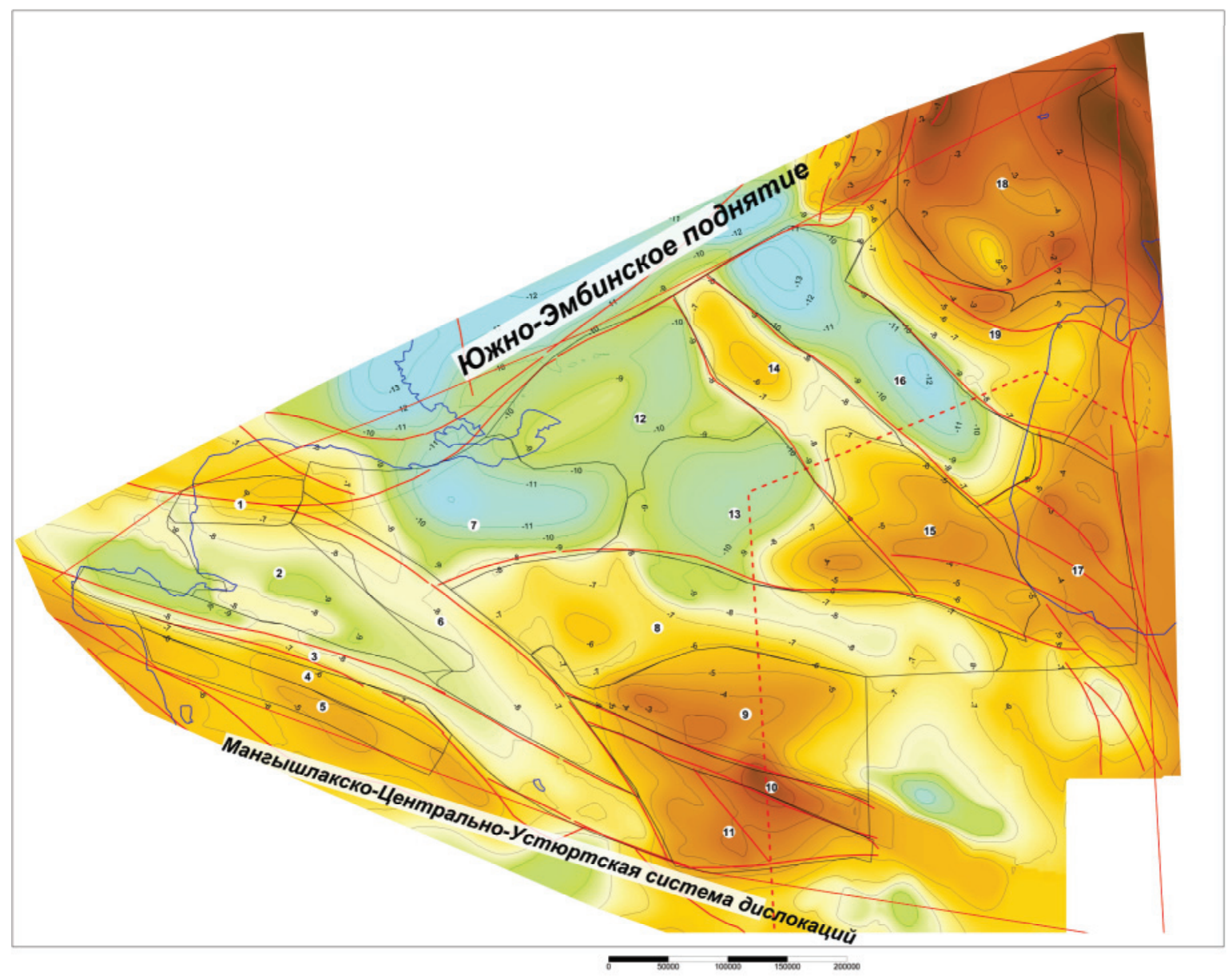

Рис. 3. Карта поверхности фундамента. Условные обозначения на карте: Тектонические элементы (по поверхности фундамента): 1 - Бузачинское поднятие; 2 - Северо-Каратаускал система; 3 - Тюбкараган- Каратауская мегантиклиналь; 4 - Чакырганский прогиб; 5 - Беке-Башкудукская мегантиклиналь; 6 - Кызан-Токубайское поднятие; 7 - Култукская впадина; 8 - Барсакельмесская впадина; 9 - Байчагырский выступ; 10 - Карабаурская мегантиклиналь; 11 - Центрально-Устюртская система; 12 - Жайылганское поднятие; 13 - Самскал впадина; 14 - Аманжол-Шелуранский выступ; 15 - Актумсукское поднятие; 16 Косбулакская впадина; 17 - Арало-Кызылкулская система; 18 - Челкарская впадина; 19 - Аккуловский выступ

Fig. 3. Map of basement surface. Legend: Tectonic elements (by basement surface): 1 - Buzachi uplift; 2 - North Karatau system; 3 - Tyubkaragan-Karatau meganticlinal; 4 - Chakirgan deflection; 5 - Beke-Bashkuduk meganticlinal; 6 - Kizan-Tokubay uplift; 7 - Kultuk depression; 8 - Barsakelmess depression; 9 - Baychagyr high; 10 - Karabaur meganticlinal; 11 - Central Ustyurt system; 12 - Zhayilgan uplift; 13 - Sams depression; 14 - Amanzhol-Sheluran high; 15-Aktumsuk uplift; 16 - Kosbulak depression; 17 - Aral-Kyzylkum system; 18 - Chelkar depression; 19 - Akkul high 
сутствие корреляции этих границ наблюдается в северо-западной и юго-восточной частях $(-0,3--0,1)$, тогда как на остальной территории Горного Мангышлака фиксируются их слабая корреляция $(0,2-0,4)$.

По подошве меловых отложений восточная часть Горного Мангышлака приподнята до 0 км, с погружением в северо-западном направлении до $2,0 \mathrm{kM}$.

Подошва меловых образований залегает неконформно вышеописанным границам раздела и характеризуется отсутствием корреляции, значения которой достигают здесь экстремально высоких величин (до -0,9) (рис. 3), что, в свою очередь, дает основание предполагать о значительной перестройке структурного плана на границе юры и мела.

Южно-Элбинское поднятие. Разделяет Прикаспийскую впадину и Северо-Устюртский массив и в виде узкой инверсионной структуры простирается в северо-восточном направлении [11].

В осевой части Южно-Эмбинского поднятия поверхность фундамента заглублена до 12,0-13,0 км, тогда как на северном и южном флангах этого поднятия воздымается до глубин 9,0-10,0 км и менее.

В рельефе поверхности палеозойских образований Южно-Эмбинское поднятие обособляется в виде крупного антиклинория с глубиной залегания поверхности палеозойского образования 1,5-4,5 км, на отдельных площадях воздымаясь до $0,5 \mathrm{\kappa м.}$

Поверхности фундамента и палеозойских отложений практически по всей территории Южно-Эмбинского поднятия залегают антиформно и не коррелируются между собой $(-0,4--0,1)$.

По глубине залегания подошвы юрских отложений Южно-Эмбинское поднятие условно можно разделить на три района. Наиболее прогнутое положение подошвы юрских образований зафиксировано в центральной части Южно-Эмбинского поднятия (3,0-3,2 км). Отсюда она воздымается до 0,6-2,0 kм на его юго-западном фланге и до 1,2-1,6 км, соответственно, на северо-восточном фланге.

Поверхность фундамента с подошвой юрских отложений коррелируется положительными значениями коэффициента (до 0,7), имея лишь в центральной части снижение этого коэффициента до 0,1 , что свидетельствует об ослаблении коррелируемости поверхности фундамента и подошвы юрских отложений.

Подошва меловых отложений имеет схожую картину по глубинам залегания. В юго-западной части Южно-Эмбинского понятия она занимает гипсометрически приподнятое положение до 0,6 км, в северо-восточной части принимает промежуточное положение и в центральной части заглублена до 1,4-1,8 км.

Арало-Кызылкулский вал (систела поднятий). По поверхности фундамента проявляет себя как крупный полигональный массив с глубиной залегания фундамента до 6,0 км.
В рельефе поверхности палеозоя на большей части своего простирания Арало-Кызылкумский вал проявляет себя как поднятие с нечетко выраженной линейной формой и глубиной погружения этой поверхности до 4,5-5,0 км.

Наблюдается уверенная корреляции между поверхностями фундамента и палеозоя (до 0,5-0,7), понижаясь до 0,1 в юго-восточной части этого вала.

Подошва юрских отложений залегает антиформно подстилающим отложениями и обладает трендом углубления в западном направлении от 1,8 до 3,4 км. Арало-Кызылкумский вал в рельефе этой поверхности приобретает четко выраженную линейную форму. Коэффициенты коррелируемсти фундамента с подошвой юрских образований варьируют в диапазоне 0,1-0,6.

Близкая тенденция проявляется в поведении поверхности меловых отложений Арало-Кызылкумского вала, которая также углубляется в западном направлении от 1,6 до 2,4 км $[12,13]$.

Фундамент с подошвой меловых отложений практически не коррелируется (до $-0,1--0,4)$. И только на отдельных площадях на западном и восточном флангах Арало-Кызылкумского вала значения этого коэффициента увеличиваются до 0,5 (рис. 3).

Актулсукская систела дислокащий и Куаныш-Коскалинский вал по поверхности фундамента обособляются на глубинах 5,0-7,0 км.

В рельефе поверхности палеозоя проявляют себя как поднятия $[13,14]$ с гипсометрическими отметками глубин залегания в пределах $3,5-4,0$ км. В центральной части Куаныш-Коскалинского вала установлено заглубление поверхности палеозойских образований до 5,0 км.

Коэффициент корреляции между поверхностями фундамента и палеозоя приобретает довольно высокие значения (до 0,6-0,8). В центральной части Куаныш-Коскалинского вала установлено снижение коррелируемости этих поверхностей раздела до 0,1 .

По подошве юры Актумсукский вал - это поднятие, обособляющееся в диапазоне глубин 2,2-2,6 км. Куаныш-Коскалинский вал отличается стабильными глубинами залегания подошвы юрских отложений (2,0 до 2,4 км).

Между поверхностью фундамента и подошвой юрских отложений устанавливаются сильные корреляционные связи для Актумсукской системы дислокаций (до 0,7). На Куаныш-Коскалинском валу значения коэффициента корреляции снижаются до 0,5 .

По подошве меловых отложений Актумсукская система дислокации обособляется на глубинах 1,6-1,8 км [13], Куаныш-Коскалинский вал - на 1,8-2,0 км $[14,15]$. Коэффициент корреляции достигает экстремально высоких значении - 0,7-0,8.

Челкарский прогиб. Обособляется на северовосточном фланге Северо-Устюртского региона. Борта этого прогиба осложнены поднятиями, группами структур, структурными террасами, антиклиналями и брахиантиклиналями [9]. 
На большей части прогиба глубина залегания фундамента установлена в диапазоне 2,0-3,0 км. В прогибе выделяются две мульды: Кургантузская и Аррадунгская. Кургантузская мульда имеет простое строение и глубину залегания фундамента до 4,0 км. Аррадунгская характеризуется сложным внутренним строением. Поверхность фундамента погружена здесь до глубины 6,0 км $[9,16]$.

По поверхности палеозоя Челкарский прогиб обособляется по изогипсе $-1,5--2,0$ км. В Аррадунгской мульде установлена его заглубление до 5,0 км. В Кургантузской мульде - до 3,5 км.

Фундамент и поверхность палеозоя в Челкарском прогибе залегает конформно с высоким коэффициентом корреляции $(0,6-0,8)$.

В рельефе подошвы юрских отложений, в бортовых зонах Челкарского прогиба, искомая поверхность выделяется на глубинах 1,0-1,4 км [16]. В депоцентрах этого прогиба она углубляется до 4,0 км в Аррадунгской мульде и до 2,4-2,6 км в Кургантузской мульде [17].

Коррелируемость фундамента с подошвой юрских образований в Челкарском прогибе снижается до $0,4-0,7$.

Подошва меловых отложений Челкарского прогиба обособляется на глубинах 0,8-1,2 км, заглубляясь до 2,8 км в Аррадунгской мульде. Отмечается высокая коррелируемость подошвы меловых отложений и фундамента $(0,6-0,8)$.

Барсакельлесский прогиб. По поверхности фундамента представляет собой сложнопостроенную асимметричную структуру с крутым северным и северо-восточным $(8,0-9,0 \mathrm{~km})$ и пологим юго-западным $(6,0-7,0$ км) бортами $[18,19]$.

По поверхности палеозоя наблюдается тренд заглубления в северном направлении от 4,0 до 6,5 км. Коэффициенты корреляции достигают экстремально высоких значений - 0,8-0,9.

В рельефе подошвы юрских отложений большая часть Барсакельмесского прогиба обособляется в виде депрессии, ориентированной в северовосточном (3,0-3,6 км) направлении, тогда как в западной, бортовой части наблюдается воздымание подошвы юрских отложений $(2,4$ км).

На большей части Барсакельмесского прогиба фиксируются высокие значения коэффициентов корреляции фундамента и подошвы юрских отложений $(0,6-0,8)$. Исключение представляют его западная и юго-восточная части, где эти границы не коррелируются (коэффициенты корреляции снижаются до $-0,4--0,1)$.

Тренд заглубления в северо-восточном направлении наблюдается и по подошве меловых отложении (1,8-2,4км) [19]. Значения коэффициента корреляции между фундаментом и подошвой мела во внутренних районах прогиба достигают здесь экстремально высоких величин (до 0,8-0,9), понижаясь до $-0,2$ в западной и юго-восточной частях.

Байчагыр-Яркилбайский свод. Крупный положительный элемент, ограничивающий Барсакельмесский прогиб с запада и обладающий массивной конфигурацией и незначительным развитием структурных осложнений в осадочном чехле [20].

На большей части этого свода поверхность фундамента погружается к северу от 4,0 до 6,0 км.

В рельефе поверхности палеозойских образований Байчагыр-Яркимбайский свод обособляется на глубинах 3,0-3,5 км.

Поверхности фундамента и палеозойских отложений практически по всей территории этого свода залегают конформно и хорошо коррелируются между собой со значениями коэффициентов корреляции $0,6-0,8$.

Подошва юрских отложений Байчагыр-Яркимбайского свода воздымается в северо-восточном направлении от 2,2 до 3,0 км [21].

Установлена высокая коррелируемость фундамента с подошвой юрских отложений (до 0,7-0,8). И только в западной части Байчагыр-Яркимбайского свода наблюдается снижение коррелируемости этих поверхностей до 0,1.

Подошва меловых отложений имеет схожий тренд коррелируемости с поверхностью фундамента. В юго-западной части Байчагыр-Яркимбайского свода она занимает гипсометрически приподнятое положение (до 1,2 км), в северо-восточной части заглублена до 1,8 км. Коэффициент корреляции здесь приобретает высокие значения (до 0,6-0,8), и только на северо-восточном фланге этого свода значения этого коэффициента снижаются до -0,1.

Северо-Устюртская система прогибов образована Самским и Косбулакским прогибами и Култукской впадиной. Эта система прогибов характеризуется глубоким погружением фундамента (до $10,0-12,0$ км и более) [22].

K югу, по сложной системе крупноамплитудных разломов [23], поверхность фундамента резко воздымается до глубин 7,0-8,0 км в Кызан-Токубайском поднятии и до 6,0-7,0 км в Актумсукской системе дислокаций.

K северу в рельефе поверхности фундамента этой системы прогибов отсутствует физическая граница с Южно-Эмбенским поднятием $(12,0-13,0 \mathrm{kм})$.

В рельефе поверхности палеозойских отложений Косбулакский и Самский прогибы обособляются на глубинах $5,5-6,5$ и $6,5-7,5 \mathrm{kм}$, соответственно, и Култукской впадине до 7,0-8,0 км.

В Северо-Устюртской системе прогибов наблюдаются высокие значения коэффициента корреляции поверхности фундамента и палеозоя (до 0,8), который снижается к границе с Южно-Эмбинским поднятием до 0,1 .

Подошва юрских отложений на большей части Северо-Устюртской системы прогибов обособляются на глубинах 3,6-4,2 км. Коэффициенты корреляции между поверхностью фундамента и подошвой юрских отложений приобретают высокие значения (до 0,7), в некоторых местах достигая максимума $(0,9)$.

В рельефе подошвы меловых отложений эта система прогибов обособляются на глубинах 
1,8-3,0 км. Наблюдаются высокие значения коэффициентов корреляции - до 0,8-0,9.

\section{Заключение}

Проведенные исследования по выявлению корреляционных связей структурных элементов в пределах крупных геоструктур Северо-Устюртского региона дают основания для формулирования следующих выводов.

В линейно-вытянутых подвижных системах и «мобильных углах" коррелируемость поверхности фундамента и палеозойских образований, подошвы юрских и меловых отложений проявляется слабо либо не проявляется вовсе. Здесь эти границы раздела зачастую залегают антиформно.

К примеру, Арало-Кызылкумская система поднятий в структуре поверхностей фундамента и палеозоя проявляет себя как вал, тогда как в строении юрских и меловых комплексов пород обособляется как погруженная депрессия.

Южно-Эмбенское поднятие в структуре отложений верхнего палеозоя и мезозоя-кайнозоя представляет собой вал, тогда как в рельефе по-

\section{СПИСОК ЛИТЕРАТУРЫ}

1. Бабаджанов Т.Л., Кунин Н.Я., Лук-Зильберман В.И. Строение и нефтегазоносность глубокопогруженных комплексов Средней Азии по геофизическим данным. - Ташкент: Фан, 1986. $190 \mathrm{c.}$

2. Неволин Н.В. Тектоника Устюрта // Геология нефти и газа. 1958. - № 07. - C. $12-18$.

3. Особенности строения палеозойских отложений ТургайскоСырдарьинского и Устюртского регионов (в связи с перспективами нефтегазоносности глубоких горизонтов осадочного чехла) / Ю.А. Волож, В.А. Быкадоров, М.П. Антипов, Р.Б. Сапожников // Нефтегазовая геология. Теория и практика. 2016. - T. 11. - № 4. - C. 1-43.

4. Ли Юн Хун. Геологическое строение и перспективы нефтегазоносности юго-восточного борта Прикаспийской впадины и ее обрамления. - М.: МГУ, 2006. - 152 с.

5. Кан В.П., Тропп Е.Б. Глубинное строение северо-восточной части Южно-Эмбинского поднятия в свете новейших сейсмических данных // Геология нефти и газа. - 1996. - № 5. C. $7-17$.

6. Taylor R. Interpretation of correlation coefficient: a basic review // SAGE journals. - 1990. - V. 6. - P. 35-39. URL: https://doi.org/ $10.1177 / 875647939000600106$ (дата обращения 30.10.2019).

7. Gogtay N.J., Thatte U.M. Principles of correlation analysis // Journals of the Association of Physicians of India. - 2017. V. 65 . - P. $78-81$.

8. Кунин Н.Я., Сапожников Р.Б. К вопросу о тектонике, перспективах нефтегазоносности и природе магнитных и гравитационных аномалий Южно-Эмбинского района // K проблеме связи Урала и Тянь-Шаня. - 1969. - № 4. - С. 10-17.

9. Парагульгов Х.Х., Куанышев М.А., Фазылов Е.М. Особенности строения и перспективы нефтегазоносности северо-востока Аральского бассейна // Известия НАН РК. - 2008. - № 6. C. $70-79$.

10. Милановский Е.Е. Геология России и ближнего зарубежья (Cеверной Евразии). - М.: МГУ, 1996. - 448 с.

11. Нефтегазоносность Северо-Устюртской впадины / А.М. Акрамходжаев, И.Г. Гринберг, В.Г. Сухинин, Ж.Ю. Юлдашев, А.А. Валиев. - Ташкент: Фан, 1974. - 81 с. верхности фундамента проявляет себя как глубокий прогиб.

Конформное залегание поверхности фундамента и палеозоя и подошвы юрских отложений в виде выступов выявлено в Центрально-Устюртской системе дислокаций, центральной части Горного Мангышлака [24, 25]. Подошва меловых отложений не коррелируется или слабо коррелируется с вышеописанными границами раздела.

Исключение составляют Бузачинский выступ, Актумсукское поднятие, Куаныш-Коскалинский вал и Байчагыр-Яркимбайский свод, характеризующиеся экстремально высокими значениями коэффициентов корреляции, проявляют себя как крупные положительные структуры по всем анализируемым границам раздела.

Внутренние районы Северо-Устюртского региона (Северо-Устюртская система прогибов, Челкарская и Барсакельмесская депрессии), характеризуются длительным и унаследованным прогибанием в фанерозое, наблюдается прогнутое положение поверхности фундамента и палеозоя, подошвы юры и мела с высокими значениями коэффициента корреляции.

12. Жолтаев Г.Ж., Исказиев К.0., Абайылданов Б.К. Палеозойские отложения - потенциальный резерв восполнения запасов и расширения сырьевой базы нефтегазовой отрасли на Мангышлаке // Известия НАН РК. Серия геологии и технических наук. - 2018. - T. 431. - № 5. - C. 163-171. URL: https://doi.org/10.32014/2018.2518-170X.22 (дата обращения 30.10 .2019 ).

13. Абетов А.Е., Ниязова А.Т., Саурыков Ж.Ж. Объемное моделирование точек Эйлера для геоплотностных и геомагнитных моделей Северо-Устюртского региона в программном пакете $\mathrm{Ge}$ osoft Oasis Montaj // Известия НАН РК. Серия геологии и технических наук. - 2017. - № 6. - С. 171-177.

14. Палеогеография и геодинамика Казахстана и сопредельных территорий / Б.С. Ужкенов, А.К. Мазуров, В.А. Быкадоров, А.В. Смирнов, 0.А. Федоренко // Доклады казахстанских геологов на МГК-32. - Алматы, 2004. - С. 39-54.

15. Жолтаев Г.Ж., Абилхасимов Х.Б. Седиментационные модели и перспективы нефтегазоносности палеозойских отложений Прикаспийской синеклизы и Устюрта. - Алматы: Казахстанское геологическое общество «КазГЕО», 2004. - 473 с.

16. Консолидированная кора Каспийского региона: опыт районирования / Ю.Г. Леонов, Ю.А. Волож, М.П. Антипов, В.А. Быкадоров, Т.Н. Хераскова. - М.: ГИН РАН, 2010. - 63 с.

17. Карта альпийской тектоники Казахстана / Б.С. Ужкенов, P.М. Антонюк, В.А. Быкадоров, Ю.А. Волож. - Алматы: Комитет геологии Казахстана, 2012. - хxх с.

18. Глубинное строение и минеральные ресурсы Казахстана / С.Ж. Даукеев, Э.С. Воцалевский, Д.А. Шлыгин, В.М. Пилифосов. - Алматы: Нефть и газ, 2002. - 248 с.

19. Пейве А.В., Марков М.С., Меннер В.В. Проблемы региональной тектоники Евразии. - М.: Академия наук СССР, Геологический институт, 1963. - Вып. 92. - ххх с.

20. Строение и нефтегазоносность палеозойских отложений Устюрта / Ю.А. Волож, В.А. Быкадоров, М.П. Антипов, В.С. Парасына, В.В. Рыбальченко // Нефть и газ. - 2013. № 5. - C. 85-97.

21. Thompson D.T. EULDPH: a new technique for making computerassisted depth estimates for magnetic data // Geophysics. 1982. - V. 47. - P. 31-37. 
22. Hood P. Gradient measurements in aeromagnetic surveying // Geophysics. - 1965. - V. XXX. - P. 891-902.

23. Reid A.B., Allsop J.M., Grancer H. Magnetic interpretation in three dimensions using Euler deconvolution // Geophysics. 1990. - V. 55. - P. 80-90.
24. Алиев И.М., Аржевский Г.А., Григоренко Ю.Н. Нефтегазоносные провинции СССР: справочник. - М.: Недра, 1983. - 272 с.

25. Таль-Вирский Б.Б. Геофизические поля и тектоника Средней Азии. - М.: Недра, 1982. - 200 с.

Поступила 14.11.2019 2.

\section{Информация об авторах}

Aбетов A.E., доктор геолого-минералогических наук, профессор, заведующий кафедрой геофизики, Казахский национальный исследовательский технический университет им. К.И. Сатпаева.

Волож Ю.А., доктор геолого-минералогических наук, главный научный сотрудник Института геологических наук РАН.

Ниязова A.T., докторант, Казахский национальный исследовательский технический университет им. К.И. Сатпаева. 
UDC 550.3385 .1

\title{
CORRELATION ANALYSIS OF THE MAIN BOUNDARIES OF A SEDIMENTARY COVER OF THE NORTH-USTYURT REGION
}

\author{
Auez E. Abetov', \\ abetov.auez@mail.ru \\ Yuriy A. Volozh², \\ yvolozh@yandex.ru \\ Akmaral T. Niyazova', \\ niyazova.akma@mail.ru \\ ${ }^{1}$ Kazakh National Research Technical University named after K. Satpaev, \\ 22, Satpaev street, Almaty, 050013, Kazakhstan. \\ 2 Institute of Geological Sciences of RAS, \\ 7, Pyzhevskiy street, Moscow, 119017, Russia.
}

\begin{abstract}
The relevance of the research is caused by the need to increase the resource base of the Republic of Kazakhstan for discovery of new oil and gas fields in the North-Ustyurt region.

The main aim of the research is to determine the correlation of structural elements of major geostuctures of North Ustyurt region.

Object: surface of the basement and Paleozoic, pre-Jurassic surface and Crateceous base of the North Ustyurt region.

Methods: conversion to digital format a series of structural maps: by the surface of the basement, Paleozoic, pre-Jurassic surface and Crateceous base of the North-Ustyurt region using Didger, Surfer, ArcGIS, Geosoft software tools; quantitative correlation analysis of the main geological boundaries in the COSCAD 3D software package.

Results. The authors have singled out three groups of geostructures in the Ustyurt region by the nature of correlation of the surface of the basement and paleozoic, the bottom of the Jurassic and Cretaceous sediments. The first group includes mobile fold systems and "mobile corners», in which the correlation coefficients are weak, either do not appear at all (South Emba uplift, Aral-Kyzylkum arch, Central Ustyurt dislocation system, Mountain Mangyshlak). The second group is formed by internal mobile groups, isolated as large positive structures characterized by extremely high values of correlation coefficients by surface of the basement and paleozoic, the bottom of the Jurassic and Cretaceous sediments (Buzachi uplift, Aktumsuk high, Kuanish-Koskala arch, Baychagyr-Yarkimbay high). The third group of geostructures is formed by tectonic elements of the inner areas of the North-Ustyurt region (North-Ustyurt depression systems, Chelkar and Barsakelmess depressions), characterized by prolonged and inherited subsidence in the Phanerozoic and high correlation surface of the basement and Paleozoic, the bottom of the Jurassic and Cretaceous sediments.
\end{abstract}

Key words:

North Ustyurt, basement, Paleozoic, Jurassic, cretaceous, correlation coefficient.

\section{REFERENCES}

1. Babadzhanov T., Kunin N., Luk-Zilberman V. Stroenie i neftegazonosnost glubokopogruzhennykh kompleksov Sredney Azii po geofizicheskim dannym [Structure and oilness of deep complexes of Central Asia by geophysical data]. Tashkent, Fan Publ., 1986. $190 \mathrm{p}$.

2. Nevolin N. Tectonika Ustyura [Tectonic of Ustyurt]. Oil and gas geology, 1958, no. 7, pp. 12-18.

3. Volozh Yu., Bykadorov V., Antipov M., Sapozhnikov R. Osobennosti stroeniya paleozoiskikh oltozheniy Turgaisko-Sirdarinskogo i Ustyurtskogo regionov (v svyazi s perspektivami neftegazonosnosti glubokikh gorizontov osadochnogo chekhla) [Structural features of the Paleozoic deposits of the Turgay-Syrdarya and Ustyurt regions (due to the oil and gas potential of the deep horizons of the sedimentary cover)]. Oil and gas Geology. Theory and Practice, 2016, vol. 4, pp. 1-43.

4. Li Yun Khun. Geologicheskoe stroenie i perspektivy neftegazonosnosti yugo-vostochnogo borta Prikaspiyskoy vpadiny i ee obramleniya [Geological structure and oil and gas perspectivity of southeastern part of Precaspian depression and its frames]. Moscow, MSU Publ., 2006. $152 \mathrm{p}$.

5. Kan V., Tropp Ye. Glubinnoe stroenie severo-vostochnoy chasti Yuzhno-Embinskogo podnyatiya v svete noveyshikh seysmicheskikh dannykh [Deep structure of north-east part of South Emba uplift in new seismic data]. Oil and gas geology, 1996, no. 5, pp. $7-17$.
6. Taylor R. Interpretation of Correlation Coefficient: a basic review. SAGE journals, 1990, vol. 6, pp. 35-39. Available at: https://doi.org/10.1177/875647939000600106 (accessed 30 0ctober 2019).

7. Gogtay N.J., Thatte U.M. Principles of correlation analysis. Journals of the Association of Physicians of India, 2017, vol. 65, pp. 78-81.

8. Kunin N., Sapozhnikov R. K voprosu o tektonike, perspektivakh neftegazonosnosti i prirode magnitnykh i gravitatsionnykh anomaliy Yuzhno-Embinskogo rayona [To the issue of tectonic, oil and gas perspectivity and nature of magnetic and gravity anomalies of South Emba area]. K probleme suyazi Urala i Tyan-Shanya, 1969, no. 4, pp. 10-17.

9. Paragulgov Kh., Kuanishev M., Fazilov E. Feature of the structure and oil and gas perspectivity of north-east of Aral basin. News of NAS RK, 2008, vol. 6, pp. 70-79. In Rus.

10. Milanovskiy E. Geologiya Rossii i blizhnego zarubezhya (Severnoy Evrazii) [Geology of Russia and neighbour foreign (North Eurasia)]. Moscow, MSU Publ., 1996. 448 p.

11. Akramkhodzhaev A., Grinberg I., Sukhinin V., Yuldashev Zh., Valiev A. Neftegazonosnost Severo-Ustyurtskoy vpadiny [Oil and gas of North Ustyurt depression]. Tashkent, Fan Publ., 1974. $81 \mathrm{p}$.

12. Zholtaev G., Iskaziev K., Abayildanov B. Paleosoic deposits as option for reserves replacement and expansion of raw material base for the petroleum industry in Mangyshlak. News of the National 
Academy of Sciences of the Republic of Kazakhstan. Series of geology and technical sciences, 2018, vol. 5, no. 431, pp. 163-171. In Rus. Available at: https://doi.org/10.32014/2018.2518-170X.22 (accessed 30 October 2019).

13. Abetov A., Niyazova A., Saurikov Zh. 3D Modeling of Euler's points for Geodensity and Geomagnetic models of North Ustyurt region in Geosoft Oasis Montaj software. News of the National Academy of Sciences of the Republic of Kazakhstan. Series of geology and technical sciences, 2017, vol. 6, no. 426, pp. 171-177. In Rus.

14. Uzhkenov B., Mazurov A., Bykadorov V., Smirnov A., Fedorenko 0. Paleogeografiya i geodinamika Kazakhstana i sopredelnykh territoriy [Paleogeography and geodynamics of Kazakhstan and adjacent territories]. Doklady kazakhstanskhikh geologov na MGK-32 [Reports of Kazakhstan geologists at MGK-32]. Almaty, 2004. pp. 39-54

15. Zholtaev G., Abilkhasimov Kh. Sedimentatsionnie basseiny i perspektivy neftegazonosnosti paleozoiskikh otlozheniy Prikaspiiskoy sineklizy $i$ Usturta [Sedimentation models and oil and gas prospects of the Paleozoic sediments of the Caspian syneclise and Ustyurt]. Almaty, Kazakhstan Geological Society «KazGEO» Publ., 2004. $473 \mathrm{p}$.

16. Leonov Yu., Volozh Yu., Antipov M., Bykadorov V., Kheraskov T. Konsolidirovannaya kora Kaspiyskogo regiona: opyt rayonirovaniya [Consolidated crust of the Caspian region: zoning experience]. Moscow, GIS RAS Publ., 2010. 63 p.

17. Uzhkenov B., Antonyuk R., Bykadorov V., Volozh Yu. Karta al piyskoy tektoniki Kazakhstana [Map of Alpian tectonic of Kazakhstan]. Almaty, Committee of geology of Kazakhstan Publ., 2012. $\mathrm{xxx}$ p.

\section{Information about the authors}

Auez E. Abetov, Dr. Sc., professor, head of Geophysics department, Kazakh National Research Technical University named after K. Satpayev.

Yuriy A. Volozh, Dr. Sc., senior researcher, Institute of Geological Sciences of RAS.

Akmaral T. Niyazova, doctoral student, Kazakh National Research Technical University named after K. Satpayev.
18. Daukeev S.Zh., Vocalevskiy E.S., Shlygin D.A., Pilifosov V.M. Glubinnoe stroenie i mineralnye resursy kazakhstana [Deep structure and mineral resources of Kazakhstan]. Almaty, Neft i gaz Publ., 2002. Vol. 3, 248 p.

19. Peive A., Markov M., Menner V. Problemy regionalnoy tektoniki Evrazii [Problems of regional tectonic of Eurasia]. Moscow, Academy of sciences of USSR, Institut of geology Publ., 1963. Iss. 92 , $\mathrm{xxx} \mathrm{p}$.

20. Volozh Yu., Bykadorov V., Antipov M., Parasina V., Rybalchenand Gas, 2013, vol. 5, pp. 85-97. In Rus.

21. Thompson D.T. EULDPH: a new technique for making computerassisted depth estimates for magnetic data. Geophysics, 1982, vol. 47, pp. 31-37.

22. Hood P. Gradient measurements in aeromagnetic surveying. Geophysics, 1965, vol. XXX, pp. 891-902.

23. Reid A.B., Allsop J.M., Grancer H. Magnetic interpretation in three dimensions using Euler deconvolution. Geophysics, 199, vol. 55 , pp. 80-90.

24. Aliyev I.M., Arzhevsky G.A., Grigorenko Yu.N. Neftegazonosnye provintsii SSSR [0il and gas provinces of the USSR]. Moscow, Nedra Publ., 1983. 272 p.

25. Tal-Virsky B.B. Geofizicheskie polya i tektonika Sredney Azii [Geophysical fields and tectonics of Central Asia]. Moscow, Nedra Publ., 1982. 200 p.

Received: 14 November 2019. ko V. Structure and oilness of Paleozoic sediments of Ustyurt. Oil 